\title{
Yün Halı İpliklerinin Boyanmasında Turunçgillerin Bazı Türlerinin Kullanımı
}

COLORS OBTAINED FROM SOME CITRUS LEAVES AND A RESEARCH ON SOME FASTNESS VALUES OF ITS COLOR

SEMA ETIKAN"-NURAN KAYABAȘ ${ }^{* *}$
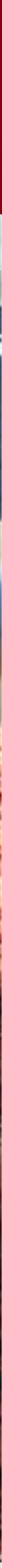

* Doç. Dr., Süleyman Demirel Üniversitesi, Güzel Sanatlar Fakültesi, Geleneksel Türk Sanatları Bölümü, Isparta.

E-posta: semaetikan@mynet.com

** Prof.Dr., Ankara Üniversitesi, Ev Ekonomisi Yüksekokulu, E1 Sanatları Bölümü, Ankara.

E-posta: kayabasinuran@gmail.com 


\section{ÖZET}

Bu çalışmada limon, portakal, mandalina ve turunç ağaçlarının yapraklarının bitkisel boyacılıkta kullanılabilirliğinin belirlenmesi ve yapılan boyamalar sonucunda elde edilen renklerle bir renk katalogu oluşturulması amaçlanmıştır. Bununla birlikte boyamalar sonucu elde edilen renklerin ışık, sürtünme ve su damlası haslık değerlerinin belirlenmesi de hedeflenmiştir. Araştırmada limon (C.limon L.), mandalina (C. reticulata Blanco), portakal (C. sinensis L.) ve turunç (C. aurantium L.) ağaçlarının kurutulmuş yaprakları kullanılarak, mordanlı ve mordansız olmak üzere toplam 68 boyama yapılmıştır. Mordanlı boyamalarda alüminyum şapı (Kal $\left.\left(\mathrm{SO}_{4}\right)_{2}\right)$, çinko klorür $\left(\mathrm{ZnCl}_{2}\right)$, kalay klorür $\left(\mathrm{SnCl}_{2}\right)$, potasyum bikromat $\left(\mathrm{K}_{2} \mathrm{Cr}_{2} \mathrm{O}_{7}\right)$, sodyum klorür $(\mathrm{NaCl})$, sodyum sülfat ( $\mathrm{Na}$ $\left.{ }_{2} \mathrm{SO}_{4}\right)$, sodyum sülfit $\left(\mathrm{Na}_{2} \mathrm{SO}_{3}\right)$, tannik asit $\left(\mathrm{C}_{76} \mathrm{H}_{52} \mathrm{O}_{46}\right)$ olmak üzere 8 adet kimyasal madde mordan olarak $\% 3$ ve $\% 5$ oranlarında kullanılmıştır. Boyamalar sonucunda başta sarı rengin çeşitli tonları olmak üzere bej, kemik rengi, bal rengi, toprak rengi, hardal, kahverengi, gül kurusu, sarı-yeşil ve yeşil-kahve renkleri ile bu renklerin açık ve koyu tonları elde edilmiştir. Turunçgil yapraklarından elde edilen renklerin ışık haslığı değerleri 2 ile 7 , sürtünme haslığı değerleri $1 / 2$ ile $4 / 5$, yaş ve kuru su damlası haslık değerleri ise 3 ile 5 değerleri arasında değişmektedir. Bu renklerin genel olarak ışık ve sürtünme haslık değerleri orta, su damlası haslık değerleri ise iyi düzeydedir.

Anahtar kelimeler: Bitkisel boyacılık, Limon (C.limon L.), Mandalina (C. reticulata Blanco), Portakal (C. sinensis L.) Turunç (C. aurantium L.), Işık hası̆ğı, Sürtünme haslığı, Su damlası haslığı

\section{ABSTRACT}

In this research, it is aimed to determining usability of some citrus leaves in naturel dyeing and form a colour catalogue by obtained colours as a result of the dyeing process. However also, it is aimed to determining of light, abrasion and water drop fastness of the colours which were obtained from these plant. Dried leaves of some citrus trees such as lemon (C.limon L.), tangerine (C. reticulata Blanco), orange (C. sinensis L.) and bitter orange (C. aurantium L.) were used as studying materials and a total of 68 dyeing processes, both with and without the aid of mordants, were realized. In dyeing with the aid of mordants, 8 different chemicals such as aluminum alum $\left(\mathrm{Kal}\left(\mathrm{SO}_{4}\right)_{2}\right)$, zinc chloride $\left(\mathrm{ZnCl}_{2}\right)$, tin chloride $(\mathrm{SnCl})$, potassium bichromate $\left(\mathrm{K}_{2} \mathrm{Cr}_{2} \mathrm{O}_{7}\right)$, sodium chloride $(\mathrm{NaCl})$, sodium sulphate $\left(\mathrm{Na}_{2} \mathrm{SO}_{4}\right)$, sodium sulphite $\left(\mathrm{Na}_{2} \mathrm{SO}_{3}\right)$, tannic acid $\left(\mathrm{C}_{76} \mathrm{H}_{52} \mathrm{O}_{46}\right)$ were used as mordants $3 \%$ and $5 \%$ in percentage terms. Various tones of yellow, beige, bone colour, amber, earth colour, mustard colour, brown, old rose colour, yellow-green and green-brown colours, dark and light tones of these colours were obtained through subjective evaluation method. The color fastness to light of this plant were found as 2 to 7 , to abrasion $1 / 2$ to 4/5, wet and dry water drop 3 to 5 .

Key words: Naturel dyeing, Lemon (C.limon L.), Tangerine (C. reticulata Blanco), Orange (C. sinensis L.), Bitter orange (C. aurantium L.), Light fastness, Abrassion fastness, Water drop fastness.

\section{1-GiRis}

Bitkisel boyac1lk Türklerde dokuma kültürü ile başlamış, gelişmiş ve dokumacilı̆ı̆n yoğun olduğu bölgelerde köklü bir gelenek oluşturmuştur. Ancak zaman içerisinde değişen ve gelişen teknoloji sonucu kimyasal boyaların kullanımının yaygınlaşması, doğal boyaların boyama tekniğinin zahmetli ve zaman alıcı olması ve elde edilen renklerin sinırlliğı gibi nedenler bir dönem Anadolu'da babadan oğula geçen bir sanat olarak yürütülen ve reçeteleri bir sır gibi saklanan bu geleneği neredeyse yok olma noktasına getirmiştir. Ancak kimyasal boya atıklarının çevreyi ve dolayısı ile insan yaşamını tehdit eden sonuçları ortaya çıktıkça, doğaya dönüş önemli olmaya başlamı̧ ve doğal boyacılık yeniden gündeme gelmiştir.

Doğal boyacılığın canlandırılması, gèliştirilmesi, geçmişteki ihtişamının yeniden kazandırılması için bu alanda yapılacak çalış- maların önemi büyüktür. Yapılacak araştırmalarla kültürel değer taşıyan bu renkler ve renk kaynakları geliştirilmeli, boyama reçetelerinin bilimsel ilkeleri ortaya konulmalıdır.

Dokumaciların büyük bir emekle, günlerce süren çalı̧̧alarının sonucu olarak ortaya çıkan renkler, yine devamında bir emeğin ve göz nurunun sonucunda zengin sanat ve kültür değerine sahip halı ve düz dokumalara dönüşmektedir. Kültürümüzü korumak, yaşatmak ve gelecek nesillere aktarmak açısından bitkisel boyacilğ̆ımızın dokuma sanatlarımızla birlikte yaşatılması önemlidir.

Çalışmada önemli el dokuması halıcilık merkezlerinden biri olan Muğla’nın bitki zenginliği içerisinde yer alan limon (C.limon L.), portakal (C. sinensis L.), mandalina (C. reticulata Blanco) ve turunç (C. aurantium L.) ağaçlarının yapraklarının bitkisel boyacilıkta kullanılabilirliğini belirlemek üzere boyama- 
lar yapılması, böylelikle kültürel değerlerimizin yaşatılması ve aktarılması açısından önem taşıyan el dokuması halı ve düz dokumalarımızla bir bütün olarak ele alınması gereken bitkisel boyacılığın geliştirilmesine katkıda bulunulması amaçlanmıştır.

Narenciye ürünleri olarak da adlandırılan turunçgiller; turunç (C. aurantium L.), portakal (C. sinensis L.), mandalina (C. reticulata Blanco), greyfurt (C. paradisi), bergamot (C. bergamia) ve limon (C.limon L.) gibi Rutaceae familyasının Citrus cinsi meyve ağacı türlerini içine alan bir bitki topluluğudur (Şekil 1. a,b,c,d). Anavatanı Çin, Güneydoğu Asya ve Hindistan olan turunçgiller genel olarak tropik ve subtropik iklim alanlarında yetişebilmektedir. Ekolojik şartlar bakımından uygun olan Türkiye'de de turunçgiller yetiştiriciliğinin oldukça eski bir geçmişi bulunmakta olup, Cumhuriyetten sonra hızla gelişmiştir. Akdeniz ve Ege Bölgesinin sahil kesimlerinde yetiştirilen ve elma ile üzümden sonra en çok ihracatı yapılan meyve grubudur. Çukurova bölgesinde Türkiye'deki toplam turunçgillerin \%70'i üretilmektedir (Akgün 2006, Anonim 2011a, Anonim 2011b, Klein et all. 1985, Ladaniya 2008, Nicolosi 2007, Timmer et all. 2000, Yokaş 2004).

Yaprak dökmeyen, yaprakları tam, derimsi ve parlak olan turunçgillerin meyveleri bol sulu, vitamin içeriği yönünden zengin, sarı ve turuncu renkli, çok gözlü, etlidir. Ayrıca meyveler lif, organik asit ve şeker yönünden zengindirler. Özellikle $\mathrm{C}$ vitamini yönünden oldukça zengin olan narenciye meyveleri, soğuk algınlıklarına, nezle ve grip gibi has- ve jöle yapılmaktadır. Gıda üretiminden arta kalan meyve posaları da hayvan yemi olarak değerlendirilmektedir. Meyveleri saran kabuklardan elde edilen esans, kolonyacilikta ve bazı gida maddelerine koku vermek amaciyla kullanılmaktadır. Aynı şekilde yapraklarından çiçeklerinden ve filizlerinden de esans üretilmektedir. Narenciye ağaçlarının kerestesi de hafif damarlı, hoş kokulu ve iyi cila kabul etmeleri nedeniyle tercih edilmektedir (Anonim, 2005, Baysal 1973, Erdoğan 2010).

Görülüyor ki turunçgillerden sanayide, meyvelerinden kerestelerine kadar geniş bir alanda yararlanılmaktadır. Ancak bitkisel boyacılıkta kullanımları ile ilgili yapılmış ayrıntılı bir çalışma bulunmamaktadır. Bu eksikliğ $i$ gidermek ve dolayısıyla bitkisel boyacılığın geliştirilmesine yönelik araştırmalara katkıda bulunmak amacıyla planlanan bu çalışmada; limon, portakal, mandalina ve turunç ağaçlarının yaprakları ile yapilan boyamalar sonucunda elde edilen renklerle bir renk katalogu oluşturulmuş ve ayrıca bu renklerin $1 s ̧ 1$, sürtünme ve su damlası haslık değerleri de belirlenmiştir.

\section{MATERYAL ve YÖNTEM 2.1.Materyal}

Araştırma materyalini limon (C.limon L.), portakal (C. sinensis L.), mandalina (C. reticulata Blanco) ve turunç (C. aurantium L.) ağaçlarının yaprakları, 2,5 numara beyaz (boyası) yün halı iplikleri ve alüminyum şapı $\left(\mathrm{Kal}\left(\mathrm{SO}_{4}\right)_{2}\right)$, çinko klorür $\left(\mathrm{ZnCl}_{2}\right)$, kalay klorür $\left(\mathrm{SnCl}_{2}\right)$, potasyum bikromat $\left(\mathrm{K}_{2} \mathrm{Cr}_{2} \mathrm{O}_{7}\right)$, sodyum klorür $(\mathrm{NaCl})$, sodyum sülfat $\left(\mathrm{Na}^{-}\right.$
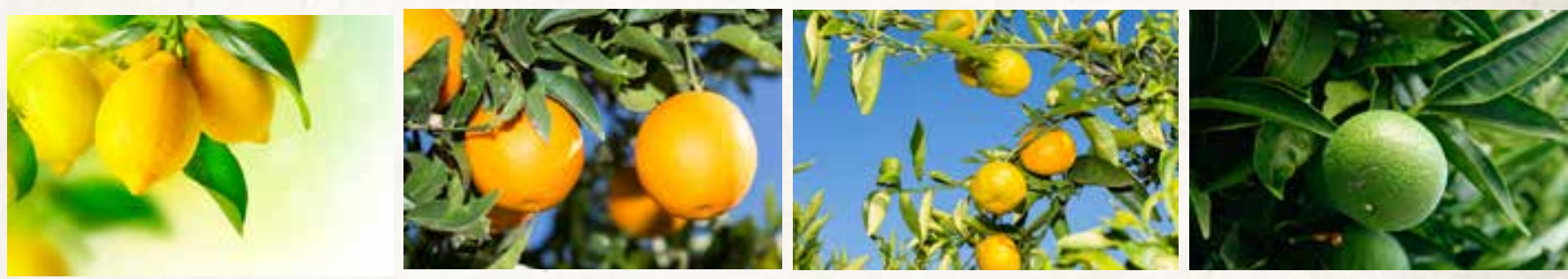

Şekil 1. a, b, c, d: a. Limon (C. limon L.), b. Portakal (C. sinensis L.), c. Mandalina (C. reticulata Blanco), d. Turunç (C. aurantium L.) (Klein et all. 1985)

talıklara iyi gelmektedir. Türunçgillerin meyveleri taze veya işlenmiş olarak tüketilmekte ve çoğunlukla meyve suyu, reçel, marmelat $\left.{ }_{2} \mathrm{SO}_{4}\right)$, sodyum sülfit $\left(\mathrm{Na}_{2} \mathrm{SO}_{3}\right)$, tannik asit $\left(\mathrm{C}_{76} \mathrm{H}_{52} \mathrm{O}_{46}\right)$ olmak üzere 10 adet kimyasal madde (mordan) oluşturmaktadır. 


\subsection{Yöntem}

Araştırmada mordanlı ve mordansız olmak üzere iki farklı boyama yöntemi uygulanmıştır. Mordanlı boyamalar ön mordanlama yöntemi ile yapılmı̧s ve materyal bölümünde belirtilen kimyasal maddeler boyanan yün halı ipliğinin ağırlı̆̆ına göre $\% 3$ ve $\% 5$ oranlarında kullanılmıştır. Bitki oranı da \%100 alınarak toplam 68 boyama yapılmıştır.

Yün halı ipliklerinin mordanla işlem görmesi: Mordan, yün halı ipliğine göre 1/50 oranında 1 lik su içerisinde eritilmiş ve önceden nemlendirilmiş yün halı ipliği bu mordanlı su içerisinde 1 saat kaynatılmıştır. Bu sürenin sonunda yün iplikler, mordanlı sudan alınarak suyu süzdürülmüş ve boyamaya hazır hale getirilmiştir.

Boya ekstraktının hazırlanması: Turunç (C. aurantium L.), portakal (C. sinensis L.), mandalina (C. reticulata Blanco) ve limon (C.limon L.) ağaçlarının kurutulmuş yaprakları, içerdiği boyarmaddenin suya geçmesini sağlamak amacıyla el yardımı ile ufalanarak küçük parçalar haline getirilmiştir. Daha sonra boyanacak yün halı ipliğine göre $1 / 50$ oranında su içerisinde 1 saat süre ile kaynatılmıştır. Bu sürenin sonunda bitki artıkları süzülerek ortamdan uzaklaştırılmış ve ekstrakt elde edilmiştir.

Mordanla işlem görmüş yün halı ipliklerinin boyanması: Daha önce mordanla işlem görmüş yün halı iplikleri elde edilen ekstrakt içerisinde 1 saat süre ile kaynatılmıştır. Sürenin tamamlanması ile dişarıya alınan iplikler kendi halinde soğumaya bırakılmış ve sonra bol su ile durulanarak 1şı almayan havadar bir yerde kurumaya bırakılmıştır.

Mordansız boyama: Önceden nemlendirilmiş yün halı iplikleri hazırlanan ekstrakt içerisinde 1 saat süre ile kaynatılmıştır. Sürenin tamamlanması ile dışarıya alınan iplikler kendi halinde soğumaya bırakılmış ve sonra bol su ile durulanarak 1şık almayan havadar bir yerde kurumaya bırakılmıştır

Elde edilen renklerin adlandırılması: Boyamalar sonucunda elde edilen renkler sübjektif ve objektif yöntemle değerlendirilmiştir.

Sübjektif yöntemle değerlendirme: Sübjektif değerlendirme için öncelikle bir komis- yon oluşturulmuştur. Doğal aydınlatmalı bir mekânda boyanmış yün halı iplikleri yandan 1ş1k gelecek şekilde beyaz zemin üzerine yerleştirilmiş ve komisyon tarafından renk farklilıklarına göre gruplandırılarak adlandırma yapılmıştır.

Işık haslığı tayini: Boyalı yün halı ipliklerinin 1şık haslığı tayini Türk Standartları Enstitüsü tarafindan TS EN ISO 105- B02/A1 (Tekstil- Renk Haslığ1 Deneyleri- Bölüm B02: Yapay Işığa Karşı Renk Haslığının Tayini-Ksenon Ark Soldurma Lambası Deneyi) (Anonim 2006a) ve DIN 5033 (Farbmessung Bergriffe Der Farbmetrik) (Anonim 1970) standartlarına göre yapılmıştır.

Sürtünme haslığı tayini: Boyalı yün halı ipliklerinin sürtünme haslığ1 tayini Türk Standartları Enstitüsü tarafindan hazırlanan TS EN ISO 105- X12 (Tekstil- Renk Haslığ1 Deneyleri- Bölüm X12: Sürtmeye Karş1 Renk Haslığ1 Tayini) (Anonim 2006b) , TS 423-3 EN 20105- A03 (Tekstil Renk Haslığ1 Tayin Metotları Bölüm A03 Renk Akmasının Değerlendirilmesinde Gri Skalaların Kullanılması) (Anonim 1996a) standartlarına göre yapılmıştır.

Su damlası haslığı tayini: Boyalı yün kilim ipliklerinin su damlası haslığı tayini Türk Standartları Enstitüsü tarafindan hazırlanan TS EN ISO 105-E07 ( Tekstil Renk Haslığ1 Deneyleri- Bölüm E07: Lekelenmeye Karşı Renk Haslığı: Su) (Anonim 2012) ve TS 423-2 EN 20105 - A02 (Tekstil Renk Haslı̆̆ 1 Tayin Metotları Bölüm A02 Solmanın Değerlendirilmesinde Gri Skalanın Kullanılması) (Anonim 1996b) standartlarına göre yapılmıştır.

\section{BULGULAR \\ 3.1. Elde edilen renkler}

Limon, portakal, mandalina ve turunç yapraklarından $\% 3$ ve $\% 5$ oranında alüminyum şapı $\left(\mathrm{Kal}\left(\mathrm{SO}_{4}\right)_{2}\right)$, çinko klorür $\left(\mathrm{ZnCl}_{2}\right)$, kalay klorür $\left(\mathrm{SnCl}_{2}\right)$, potasyum bikromat $\left(\mathrm{K}_{2} \mathrm{Cr}_{2} \mathrm{O}_{7}\right)$, sodyum klorür $(\mathrm{NaCl})$, sodyum sülfat $\left(\mathrm{Na}^{-}\right.$ $\left.{ }_{2} \mathrm{SO}_{4}\right)$, sodyum sülfit $\left(\mathrm{Na}_{2} \mathrm{SO}_{3}\right)$, tannik asit $\left(\mathrm{C}_{76} \mathrm{H}_{52} \mathrm{O}_{46}\right)$ mordanlar1 ile \%100 oranında bitki kullanılarak mordanlı ve mordansız olmak üzere yapilan toplam 68 boyama sonu- 
YÜN HALI IPLIKLERININ BOYANMASINDA TURUNÇGILLERIN BAZI TÜRLERININ KULLANIM

\section{SEMA ETIKAN-NURAN KAYABAȘI}

\begin{tabular}{|c|c|c|c|c|c|}
\hline \multirow[b]{2}{*}{ Mordan Adl } & \multirow{2}{*}{$\begin{array}{l}\text { Mordan } \\
\text { Oranı } \\
(\%)\end{array}$} & \multicolumn{4}{|c|}{ Sübjektif Değerlendirme } \\
\hline & & Limon yaprakları & $\begin{array}{l}\text { Portakal } \\
\text { yapraklart }\end{array}$ & Mandalina yaprakları & $\begin{array}{l}\text { Turunç } \\
\text { yapraklart }\end{array}$ \\
\hline \multirow{2}{*}{$\begin{array}{l}\text { Alüminyum } \\
\text { Şapı }\end{array}$} & $\% 3$ & Sarl & Açık sarı & Saman sarısı & Saman sarlst \\
\hline & $\% 5$ & Sarımsı yeşil & Açık sarı & Açık kirli sarı & Kirli sart \\
\hline \multirow{2}{*}{ Çinko Klorür } & $\% 3$ & Açık sarı & Açık sarı & Sarl Yeşil & $B e j$ \\
\hline & $\% 5$ & Saman sarlsl & Yeşil sart & Açık zeytinyă̆ & Kirli sarl \\
\hline \multirow{2}{*}{ Kalay Klorür } & $\% 3$ & Açık bal rengi & Bal rengi & Bal rengi & Kirli Sart \\
\hline & $\% 5$ & Civciv sarlst & Açık civciv sarısı & Civciv sarist & Açık hardal \\
\hline \multirow{2}{*}{ Sodyum Sülfat } & $\% 3$ & Bal rengi & $B e j$ & Zeytinyağ & $B e j$ \\
\hline & $\% 5$ & Kemik rengi & Açık sarl & Koyu sarl & Kirli sarl \\
\hline \multirow{2}{*}{ Sodyum Sülfit } & $\% 3$ & Sarl & Açık sarl & Açık su yeşili & $B e j$ \\
\hline & $\% 5$ & $B e j$ & Kirli sarl & Açık sarı & Sarl \\
\hline \multirow{2}{*}{ Sodyum Klorür } & $\% 3$ & Açık sarl & $B e j$ & Açık haki & Kirli Sarl \\
\hline & $\% 5$ & Saman sarlst & Kirli sart & Koyu sarımsı yeşil & Açık hardal \\
\hline \multirow{2}{*}{$\begin{array}{l}\text { Potasyum } \\
\text { bikromat }\end{array}$} & $\% 3$ & Hardal & Koyu su yeşili & Koyu hardal & Hardal \\
\hline & $\% 5$ & $B e j$ & Açık sarl & Hardal & Kirli sarl \\
\hline \multirow{2}{*}{ Tannik asit } & $\% 3$ & Sütlü kahve & Koyu toprak & Yeşil Kahve & Açık sütlü kahve \\
\hline & $\% 5$ & Gül kurusu & Koyu gül kurusu & Açık kahve & Toprak rengi \\
\hline Mordansiz & & Açık saman sarısı & Kirli sart & Sarımsı yeşil & Sarımsı krem \\
\hline
\end{tabular}

Çizelge 1. Limon, portakal, mandalina ve turunç yapraklarından elde edilen renkler

cunda elde edilen renkler sübjektif değerlendirme yöntemi ile belirlenmiş ve Çizelge 1'de verilmiştir.
Çizelge 1 incelendiğinde, sübjektif değerlendirmeye göre limon yaprakları ile mordan kullanılarak yapilan boyamalar sonucunda

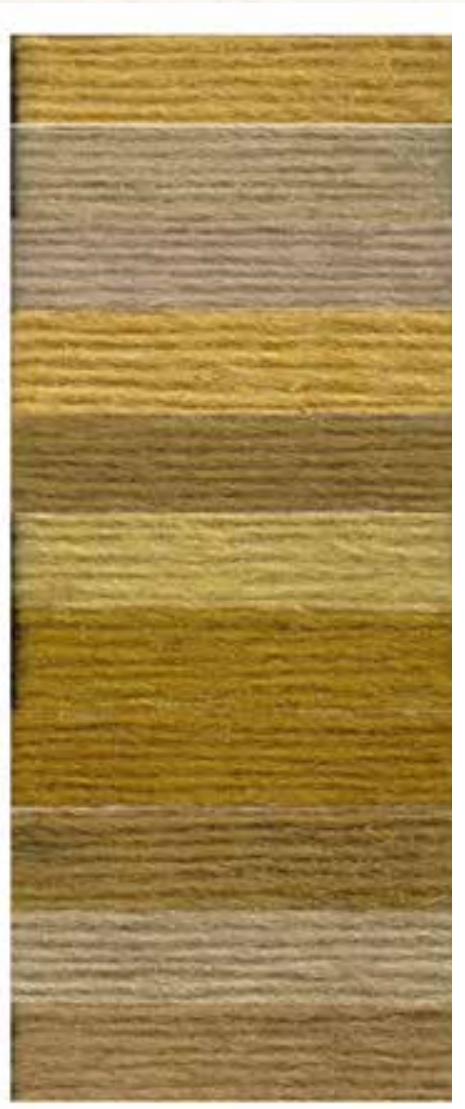

Elde edilen bazt renkler ve elde edilme yountemleri

Sarı (Limon yapraklari/Alïminyum şaps-\%3)

Açık bal rengi (Limon yaprakları/Kalay korür-\%3)

Sïtlü kahve (Limon yapraklari/Tannik asit-\%3)

Açık sarı (Portakal yapraklart/Alitminyum şapu-\%3)

Yeșil sarı (Portakal yapraktarn/Cinko klonïr-\%5)

Saman sarısı (Mandalina yaprakları/ Alïminyzum şapt-\%3)

Açık zeytinyağı (Mandalina yapraklarz/Cinko klorür-\%5)

Hardal (Mandalina yapraklari/ Potasymm biknomat-95)

Açık haki (Mandalina yapraklarz/Soyıum klörūrr-\%33)

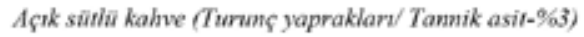

Toprak rengi (Turunç yapraklard Tannik asit-\%5)

Çizelge 2. Limon, portakal, mandalina ve turunç yapraklarından elde edilen bazı renkler 


\begin{tabular}{|c|c|c|c|c|c|}
\hline \multirow[t]{2}{*}{ Mordan Adl } & \multirow{2}{*}{$\begin{array}{c}\text { Mordan Orant } \\
\text { (\%) }\end{array}$} & \multirow[t]{2}{*}{ Işık Haslı̆̆ } & \multirow{2}{*}{$\begin{array}{c}\text { Sürtünme } \\
\text { Haslı̆̆ }\end{array}$} & \multicolumn{2}{|c|}{ Su Damlası Haslığı } \\
\hline & & & & Yaş & Kuru \\
\hline \multirow[t]{2}{*}{ Alüminyum Şapı } & $\% 3$ & 4 & 3 & $4 / 5$ & 5 \\
\hline & $\% 5$ & 3 & $3 / 4$ & 5 & 5 \\
\hline \multirow[t]{2}{*}{ Çinko Klorür } & $\% 3$ & 3 & $3 / 4$ & 5 & 5 \\
\hline & $\% 5$ & 3 & 3 & 4 & 5 \\
\hline \multirow[t]{2}{*}{ Sodyum Sülfat } & $\% 3$ & 3 & 4 & 5 & 5 \\
\hline & $\% 5$ & 2 & 4 & $4 / 5$ & $4 / 5$ \\
\hline \multirow[t]{2}{*}{ Sodyum Sülfit } & $\% 3$ & 3 & 4 & $4 / 5$ & $4 / 5$ \\
\hline & $\% 5$ & 3 & $3 / 4$ & 4 & 5 \\
\hline \multirow[t]{2}{*}{ Sodyum Klorür } & $\% 3$ & 3 & 4 & $4 / 5$ & 5 \\
\hline & $\% 5$ & 3 & $3 / 4$ & $4 / 5$ & 5 \\
\hline \multirow{2}{*}{ Kalay Klorür } & $\% 3$ & 3 & 3 & 5 & 5 \\
\hline & $\% 5$ & 4 & $3 / 4$ & 5 & 5 \\
\hline \multirow{2}{*}{$\begin{array}{l}\text { Potasyum } \\
\text { Bikromat }\end{array}$} & $\% 3$ & 6 & 3 & $3 / 4$ & 5 \\
\hline & $\% 5$ & 4 & $3 / 4$ & 3 & $4 / 5$ \\
\hline \multirow[t]{2}{*}{ Tannik Asit } & $\% 3$ & 4 & $2 / 3$ & 3 & 4 \\
\hline & $\% 5$ & 3 & 3 & $4 / 5$ & 5 \\
\hline Mordansiz & & 4 & 4 & $3 / 4$ & 5 \\
\hline
\end{tabular}

Çizelge 3. Limon yapraklarından elde edilen renklerin haslık değerleri

sarı, sarımsı yeşil, açık sarı, saman sarısı, açık bal rengi, civciv sarısı, bal rengi, kemik rengi, bej, hardal, sütlü kahve, gül kurusu, açık saman sarısı renklerinin, mordansiz boyama sonucunda ise açık saman sarısı renginin elde edildiği görülmektedir.

Portakal yaprakları ile mordan kullanılarak yapılan boyamalar sonucunda açık sarı, yeşil sarı, bal rengi, açık civciv sarısı, bej, kirli sarı, koyu su yeşili, koyu toprak ve koyu gül kurusu renklerinin, mordansız boyama sonucunda ise kirli sarı renginin elde edildiği görülmektedir.

Mandalina yaprakları ile mordan kullanılarak yapilan boyamalar sonucunda saman sarısı, açık kirli sarı, sarı yeşil, açık zeytinyağı, yeşil kahve, bal rengi, civciv sarısı, zeytinyağı, koyu sarı, açık su yeşili, açık sarı, açık haki, koyu sarımsı yeşil, koyu hardal, hardal, açık kahve renklerinin, mordansiz boyama sonucunda ise sarımsı yeşil renginin elde edildiği görülmektedir.

Turunç yaprakları ile mordan kullanılarak yapilan boyamalar sonucunda saman sarıs1, kirli sarı, bej, sarı, açık hardal, hardal, açık sütlü kahve, toprak rengi, renklerinin, mordansız boyama sonucunda ise sarımsı krem renginin elde edildiği görülmektedir.
Çizelge 2'de yapılan 68 boyama sonucunda elde edilen renklerin bazılarına ait örnekler verilmiştir.

\subsection{Elde edilen renklerin haslık değerleri}

Limon yapraklarindan elde edilen renklerin 1şık, sürtünme ve su damlası haslık degerleri: Limon yapraklarından $\% 3$ ve $\% 5$ oranında alüminyum şapı $\left(\mathrm{Kal}\left(\mathrm{SO}_{4}\right)_{2}\right)$, çinko klorür $\left(\mathrm{ZnCl}_{2}\right)$, kalay klorür $\left(\mathrm{SnCl}_{2}\right)$, potasyum bikromat $\left(\mathrm{K}_{2} \mathrm{Cr}_{2} \mathrm{O}_{7}\right)$, sodyum klorür $(\mathrm{NaCl})$, sodyum sülfat $\left(\mathrm{Na}_{2} \mathrm{SO}_{4}\right)$, sodyum sülfit $(\mathrm{Na}-$ $\left.{ }_{2} \mathrm{SO}_{3}\right)$, tannik asit $\left(\mathrm{C}_{76} \mathrm{H}_{52} \mathrm{O}_{46}\right)$ mordanlar1 ile \%100 oranında bitki kullanılarak mordanlı ve mordansız olmak üzere yapilan toplam 17 boyama sonucunda elde edilen renklerin 1şık, sürtünme ve su damlası haslık değerleri belirlenmiş ve Çizelge 3'de verilmiştir.

Çizelge 3. incelendiğinde limon yapraklarından elde edilen renklerin 1şık haslıklarının 2 ile 6 değerleri arasında değiştiği görülmektedir. En düşük değer olan 2 değeri sodyum sülfat ile $\% 5$ oranında yapılan, en yüksek değer olan 6 değeri ise potasyum bikromat ile $\% 3$ oranında yapılan boyamalarda elde edilmiştir. 
Sürtünme haslığ 1 değerleri $2 / 3$ ile 4 değerleri arasında değişmektedir. En düşük değer olan $2 / 3$ değeri tannik asit ile $\% 3$ oranında yapılan, en yüksek değer olan 4 değeri ise sodyum sülfat ile $\% 3$ ve $\% 5$ oranlarında, sodyum sülfit ve sodyum klorür ile \%3 oranlarında ve mordansız yapilan boyamalarda elde edilmiştir.

Yaş su damlası haslık değerleri 3 ile 5, kuru su damlası haslık değerleri 4 ile 5 değerleri
Portakal yapraklarından \%3 ve \%5 oranında alüminyum şapı $\left(\mathrm{Kal}\left(\mathrm{SO}_{4}\right)_{2}\right)$, çinko klorür $\left(\mathrm{ZnCl}_{2}\right)$, kalay klorür $\left(\mathrm{SnCl}_{2}\right)$, potasyum bikromat $\left(\mathrm{K}_{2} \mathrm{Cr}_{2} \mathrm{O}_{7}\right)$, sodyum klorür $(\mathrm{NaCl})$, sodyum sülfat $\left(\mathrm{Na}_{2} \mathrm{SO}_{4}\right)$, sodyum sülfit $(\mathrm{Na}$ $\left.{ }_{2} \mathrm{SO}_{3}\right)$, tannik asit $\left(\mathrm{C}_{76} \mathrm{H}_{52} \mathrm{O}_{46}\right)$ mordanlari ile $\% 100$ oranında bitki kullanılarak mordanlı ve mordansız olmak üzere yapilan toplam 17 boyama sonucunda elde edilen renklerin $1 s ̧ 1 \mathrm{k}$,

\begin{tabular}{|c|c|c|c|c|c|}
\hline \multirow[t]{2}{*}{ Mordan Adı } & \multirow{2}{*}{$\begin{array}{c}\text { Mordan } \\
\text { Oranı (\%) }\end{array}$} & \multirow[t]{2}{*}{ Işık Haslı̆̆ı } & \multirow[t]{2}{*}{ Sürtünme Haslı̆̆ı } & \multicolumn{2}{|c|}{ Su Damlası Haslığı } \\
\hline & & & & Yaş & Kuru \\
\hline \multirow{2}{*}{ Alüminyum Şapı } & $\% 3$ & 3 & $3 / 4$ & 5 & 5 \\
\hline & $\% 5$ & 3 & $3 / 4$ & 5 & 5 \\
\hline \multirow[t]{2}{*}{ Çinko Klorür } & $\% 3$ & 3 & $2 / 3$ & 5 & 5 \\
\hline & $\% 5$ & 3 & $3 / 4$ & 5 & $4 / 5$ \\
\hline \multirow[t]{2}{*}{ Sodyum Sülfat } & $\% 3$ & 5 & 3 & 5 & 4 \\
\hline & $\% 5$ & 3 & 3 & 5 & 5 \\
\hline \multirow[t]{2}{*}{ Sodyum Sülfit } & $\% 3$ & 3 & 4 & 5 & 5 \\
\hline & $\% 5$ & 3 & $4 / 5$ & 5 & $4 / 5$ \\
\hline \multirow[t]{2}{*}{ Sodyum Klorür } & $\% 3$ & 5 & 4 & 5 & 4 \\
\hline & $\% 5$ & 4 & $3 / 4$ & 5 & 4 \\
\hline \multirow[t]{2}{*}{ Kalay Klorür } & $\% 3$ & 3 & 4 & 5 & 5 \\
\hline & $\% 5$ & 3 & 4 & 5 & $4 / 5$ \\
\hline \multirow[t]{2}{*}{ Potasyum Bikromat } & $\% 3$ & 3 & 4 & 4 & $3 / 4$ \\
\hline & $\% 5$ & 3 & $3 / 4$ & 5 & 5 \\
\hline \multirow[t]{2}{*}{ Tannik Asit } & $\% 3$ & 3 & $3 / 4$ & 5 & $4 / 5$ \\
\hline & $\% 5$ & 3 & 3 & 5 & 4 \\
\hline Mordansiz & & 2 & 3 & $4 / 5$ & 4 \\
\hline
\end{tabular}

Çizelge 4. Portakal yapraklarından elde edilen renklerin haslık değerleri

arasında değişmektedir. Yaş su damlası için en düşük değer olan 3 değeri potasyum bikromat ile $\% 5$ oranında ve tannik asit ile $\% 3$ oranında yapılan, en yüksek değer olan 5 değeri ise çinko klorür ve sodyum sülfat ile $\% 3$ oranında, kalay klorür ile $\% 3$ ve $\% 5$ oranlarında yapılan boyamalarda elde edilmiştir. Kuru su damlası için en düşük değer olan 4 değeri tannik asit ile \%3 oranında yapılan boyamada elde edilmiştir. En yüksek değer olan 5 değerine ise boyamaların büyük bir çoğunluğunun sonucunda ulaşılmıştır.

Limon yapraklarından elde edilen renklerin 1şık haslıkları genelde orta düzeyde, sürtünme ve su damlası haslıkları orta ve iyi düzeydedir.

\section{Portakal yapraklarından elde edilen renklerin 1şık, sürtünme ve su damlası haslık değerleri}

sürtünme ve su damlası haslık değerleri belirlenmiş ve Çizelge 4'de verilmiştir.

Çizelge 4. incelendiğinde portakal yapraklarından elde edilen renklerin 1 şık haslıklarının 2 ile 5 değerleri arasında değiştiği görülmektedir. En düşük değer olan 2 değeri mordansız yapılan, en yüksek değer olan 5 değeri ise sodyum sülfat ve sodyum klorür ile $\% 3$ oranında yapılan boyamalarda elde edilmiştir.

Sürtünme haslı̆̆ 1 değerleri $2 / 3$ ile $4 / 5$ değerleri arasında değişmektedir. En düşük değer olan $2 / 3$ değeri çinko klorür ile $\% 3$ oranında yapılan, en yüksek değer olan $4 / 5$ değeri ise sodyum sülfit ile $\% 5$ oranında yapılan boyamalarda elde edilmiştir.

Yaş su damlası haslık değerleri 4 ile 5, kuru su damlası haslık değerleri 3/4 ile 5 değerleri arasında değişmektedir. Yaş su damlası için en düşük değer olan 4 değeri potasyum bikromat 
ile \%3 oranında yapılan boyamalarda elde edilmiştir. En yüksek değer olan 5 değerine ise boyamaların büyük bir çoğunluğunun sonucunda ulaşılmıştır. Kuru su damlası için en düşük değer olan 3/4 değeri potasyum bikromat ile \%3 oranında yapılan, en yüksek değer olan 5 değeri ise alüminyum şapı ile $\% 3$ ve $\% 5$ oranlarında, çinko klorür ile $\% 3$ oranında, sodyum sülfat ile $\% 5$ oranında, sodyum sülfit $\% 3$ oranında, kalay klorür ile $\% 3$ oranında, potasyum bikromat ile $\% 5$ oranında yapılan boyamalarda elde edilmiştir.

Portakal yapraklarından elde edilen renklerin 1şı ve sürtünme haslıkları genelde orta düzeyde, su damlası haslıkları iyi düzeydedir.

\section{Mandalina yapraklarından elde edilen renklerin 1şık, sürtünme ve su damlası haslık değerleri}

Mandalina yapraklarından \%3 ve \%5 oranında alüminyum şapı $\left(\mathrm{Kal}\left(\mathrm{SO}_{4}\right)_{2}\right)$, çinko klorür $\left(\mathrm{ZnCl}_{2}\right)$, kalay klorür $\left(\mathrm{SnCl}_{2}\right)$, potasyum bikromat $\left(\mathrm{K}_{2} \mathrm{Cr}_{2} \mathrm{O}_{7}\right)$, sodyum klorür $(\mathrm{NaCl})$, sodyum sülfat $\left(\mathrm{Na}_{2} \mathrm{SO}_{4}\right)$, sodyum sülfit $(\mathrm{Na}-$ $\left.{ }_{2} \mathrm{SO}_{3}\right)$, tannik asit $\left(\mathrm{C}_{76} \mathrm{H}_{52} \mathrm{O}_{46}\right)$ mordanlar1 ile $\% 100$ oranında bitki kullanılarak mordanlı ve mordansız olmak üzere yapilan toplam 17 boyama sonucunda elde edilen renklerin $1 s ̧ 1 \mathrm{k}$, sürtünme ve su damlası haslık değerleri belirlenmiş ve Çizelge 5'de verilmiştir.

Çizelge 5. İncelendiğinde mandalina yap- raklarından elde edilen renklerin 1 şı haslıklarının 2 ile 7 değerleri arasında değiştiği görülmektedir. En düşük değer olan 2 değeri sodyum sülfat ile $\% 5$ oranında yapılan, en yüksek değer olan 7 değeri ise potasyum bikromat ile $\% 3$ ve $\% 5$ oranlarında yapilan boyamalarda elde edilmiştir.

Sürtünme haslığ 1 değerleri 2 ile 4/5 değerleri arasında değişmektedir. En düşük değer olan 2 değeri tannik asit ile $\% 3$ oranında yapilan, en yüksek değer olan 4/5 değeri ise sodyum sülfit ile $\% 5$ oranında yapılan boyamalarda elde edilmiştir.

Yaş su damlası haslık değerleri $4 / 5$ ile 5 değerleri kuru su damlası haslık değerleri 4 ile 5 değerleri arasında değişmektedir. Yaş su damlası için en düşük değer olan 4/5 değeri potasyum bikromat ile $\% 3$ ve $\% 5$ oranlarında yapılan boyamalarda elde edilmiştir. En yüksek değer olan 5 değerine ise boyamaların büyük bir çoğunluğunun sonucunda ulaş1lmıştır. Kuru su damlası için en düşük değer olan 4 değeri alüminyum şapı ile $\% 3$ oranında, sodyum sülfat ve kalay klorür ile $\% 5$ oranında yapilan, en yüksek değer olan 5 değerine ise yine boyamaların büyük bir çoğunluğunun sonucunda ulaşılmıştır.

Mandalina yapraklarından elde edilen renklerin 1 ş1k ve sürtünme haslıkları genelde orta düzeyde, su damlası haslıkları iyi düzeydedir.

\begin{tabular}{|c|c|c|c|c|c|}
\hline \multirow[t]{2}{*}{ Mordan Adı } & \multirow{2}{*}{$\begin{array}{c}\text { Mordan Orant } \\
\text { (\%) }\end{array}$} & \multirow[t]{2}{*}{ Işıı Haslığı } & \multirow[t]{2}{*}{ Sürtünme Haslığı } & \multicolumn{2}{|c|}{ Su Damlası Haslığ } \\
\hline & & & & Yaş & Kuru \\
\hline \multirow{2}{*}{ Alüminyum Şapı } & $\% 3$ & 4 & $2 / 3$ & 5 & 4 \\
\hline & $\% 5$ & 4 & 3 & 5 & 5 \\
\hline \multirow[t]{2}{*}{ Çinko Klorür } & $\% 3$ & 3 & 3 & 5 & 5 \\
\hline & $\% 5$ & 3 & $2 / 3$ & 5 & $4 / 5$ \\
\hline \multirow[t]{2}{*}{ Sodyum Sülfat } & $\% 3$ & 3 & 3 & 5 & $4 / 5$ \\
\hline & $\% 5$ & 2 & $3 / 4$ & 5 & 4 \\
\hline \multirow[t]{2}{*}{ Sodyum Sülfit } & $\% 3$ & 3 & 4 & 5 & 5 \\
\hline & $\% 5$ & 3 & $4 / 5$ & 5 & 5 \\
\hline \multirow{2}{*}{ Sodyum Klorür } & $\% 3$ & 4 & 3 & 5 & 5 \\
\hline & $\% 5$ & 3 & $3 / 4$ & 5 & 5 \\
\hline \multirow[t]{2}{*}{ Kalay Klorür } & $\% 3$ & 3 & $2 / 3$ & 5 & $4 / 5$ \\
\hline & $\% 5$ & 3 & $2 / 3$ & 5 & 4 \\
\hline \multirow[t]{2}{*}{ Potasyum Bikromat } & $\% 3$ & 7 & 3 & $4 / 5$ & $4 / 5$ \\
\hline & $\% 5$ & 7 & $3 / 4$ & $4 / 5$ & $4 / 5$ \\
\hline \multirow[t]{2}{*}{ Tannik Asit } & $\% 3$ & 3 & 2 & 5 & 5 \\
\hline & $\% 5$ & 3 & $2 / 3$ & 5 & 5 \\
\hline Mordansiz & & 5 & 3 & 5 & $4 / 5$ \\
\hline
\end{tabular}

Çizelge 5. Mandalina yapraklarından elde edilen renklerin haslık değerleri 
Turunç yapraklarından elde edilen renklerin 1şık, sürtünme ve su damlası haslık değerleri

Turunç yapraklarından $\% 3$ ve $\% 5$ oranında alüminyum şapı $\left(\mathrm{Kal}\left(\mathrm{SO}_{4}\right)_{2}\right)$, çinko klorür $\left(\mathrm{ZnCl}_{2}\right)$, kalay klorür $\left(\mathrm{SnCl}_{2}\right)$, potasyum bikromat $\left(\mathrm{K}_{2} \mathrm{Cr}_{2} \mathrm{O}_{7}\right)$, sodyum klorür $(\mathrm{NaCl})$, sodyum sülfat $\left(\mathrm{Na}_{2} \mathrm{SO}_{4}\right)$, sodyum sülfit $\left(\mathrm{Na}_{2} \mathrm{SO}_{3}\right)$, tannik asit $\left(\mathrm{C}_{76} \mathrm{H}_{52} \mathrm{O}_{46}\right)$ mordanları ile \%100 oranında bitki kullanilarak mordanlı ve mordansız olmak üzere yapılan toplam 17 boyama sonucunda elde edilen renklerin $1 s ̧ 1$, sürtünme ve su damlası haslık değerleri belirlenmiş ve Çizelge 6 'da verilmiştir. olan $1 / 2$ değeri tannik asit ile $\% 5$ oranında yapilan, en yüksek değer olan $3 / 4$ değeri ise çinko klorür ve sodyum sülfit ile $\% 3$ ve $\% 5$ oranlarında sodyum klorür ile $\% 3$ oranında ve mordansız yapılan boyamalarda elde edilmiştir.

Yaş su damlası haslık değerleri 4 ile 5 değerleri kuru su damlası haslık değerleri 3 ile 5 değerleri arasında değişmektedir. Yaş su damlası için en düşük değer olan 4 değeri sodyum klorür ve tannik asit ile \%5 oranında yapılan boyamalarda elde edilmiştir. En yüksek değer olan 5 değerine ise boyamaların büyük bir çoğunluğunun sonucunda ulaşılmıştır. Kuru su damlası için en düşük değer olan 3 değeri sodyum sülfat, kalay

\begin{tabular}{|c|c|c|c|c|c|}
\hline \multirow[t]{2}{*}{ Mordan Adl } & \multirow{2}{*}{$\begin{array}{c}\text { Mordan } \\
\text { Orant (\%) }\end{array}$} & \multirow[t]{2}{*}{ Işık Haslı̆̆g } & \multirow[t]{2}{*}{ Sürtünme Haslığı } & \multicolumn{2}{|c|}{ Su Damlası Haslığı } \\
\hline & & & & Yaș & Киги \\
\hline \multirow[t]{2}{*}{ Alüminyum Şapı } & $\% 3$ & 3 & 3 & 5 & $3 / 4$ \\
\hline & $\% 5$ & 3 & $2 / 3$ & $4 / 5$ & $3 / 4$ \\
\hline \multirow[t]{2}{*}{ Çinko Klorür } & $\% 3$ & 3 & $3 / 4$ & 5 & $4 / 5$ \\
\hline & $\% 5$ & 4 & $3 / 4$ & 5 & 5 \\
\hline \multirow[t]{2}{*}{ Sodyum Sülfat } & $\% 3$ & 3 & 4 & 5 & $3 / 4$ \\
\hline & $\% 5$ & 3 & 4 & 5 & 3 \\
\hline \multirow[t]{2}{*}{ Sodyum Sülfit } & $\% 3$ & 5 & $3 / 4$ & 5 & 4 \\
\hline & $\% 5$ & 4 & $3 / 4$ & 5 & $4 / 5$ \\
\hline \multirow[t]{2}{*}{ Sodyum Klorür } & $\% 3$ & 4 & $3 / 4$ & 5 & 4 \\
\hline & $\% 5$ & 5 & 3 & 4 & $3 / 4$ \\
\hline \multirow[t]{2}{*}{ Kalay Klorür } & $\% 3$ & 3 & 3 & 5 & 5 \\
\hline & $\% 5$ & 3 & 3 & 5 & 3 \\
\hline \multirow[t]{2}{*}{ Potasyum Bikromat } & $\% 3$ & 6 & $2 / 3$ & 5 & $3 / 4$ \\
\hline & $\% 5$ & 3 & 3 & 5 & 3 \\
\hline \multirow[t]{2}{*}{ Tannik Asit } & $\% 3$ & 5 & 2 & 5 & $4 / 5$ \\
\hline & $\% 5$ & 3 & $1 / 2$ & 4 & 4 \\
\hline Mordansiz & & 3 & $3 / 4$ & $4 / 5$ & 4 \\
\hline
\end{tabular}

Çizelge 6. Turunç yapraklarından elde edilen renklerin haslık değerleri

Çizelge 6 incelendiğinde turunç yapraklarından elde edilen renklerin ışık haslıklarının 3 ile 6 değerleri arasında değiştiği görülmektedir. En düşük değer olan 3 değeri alüminyum şapı ile $\% 3$ ve $\% 5$ oranlarında, çinko klorür ile $\% 3$ oranında, sodyum sülfat ve kalay klorürle $\% 3$ ve $\% 5$ oranlarında, potasyum bikromat ve tannik asit ile $\% 5$ oranında ve mordansız yapılan, en yüksek değer olan 6 değeri ise potasyum bikromat ile $\% 3$ oranında yapılan boyamalarda elde edilmiştir.

Sürtünme haslığı değerleri 1/2 ile 3/4 değerleri arasında değişmektedir. En düşük değer klorür ve potasyum bikromat ile $\% 5$ oranında yapılan, en yüksek değer olan 5 değerine ise çinko klorür ile $\% 5$ oranında, kalay klorür ile $\% 3$ oranında yapılan boyamalarda elde edilmiştir.

Turunç yapraklarından elde edilen renklerin 1şık ve sürtünme haslıkları genelde orta düzeyde, su damlası haslıklarından yaş su damlası haslığı değerleri iyi, kuru su damlası haslığı değerleri ise orta düzeydedir.

\section{SONUC}

Araştırmada Ege Bölgesinin Muğla İlinde yetişen limon, portakal, mandalina ve turunç 


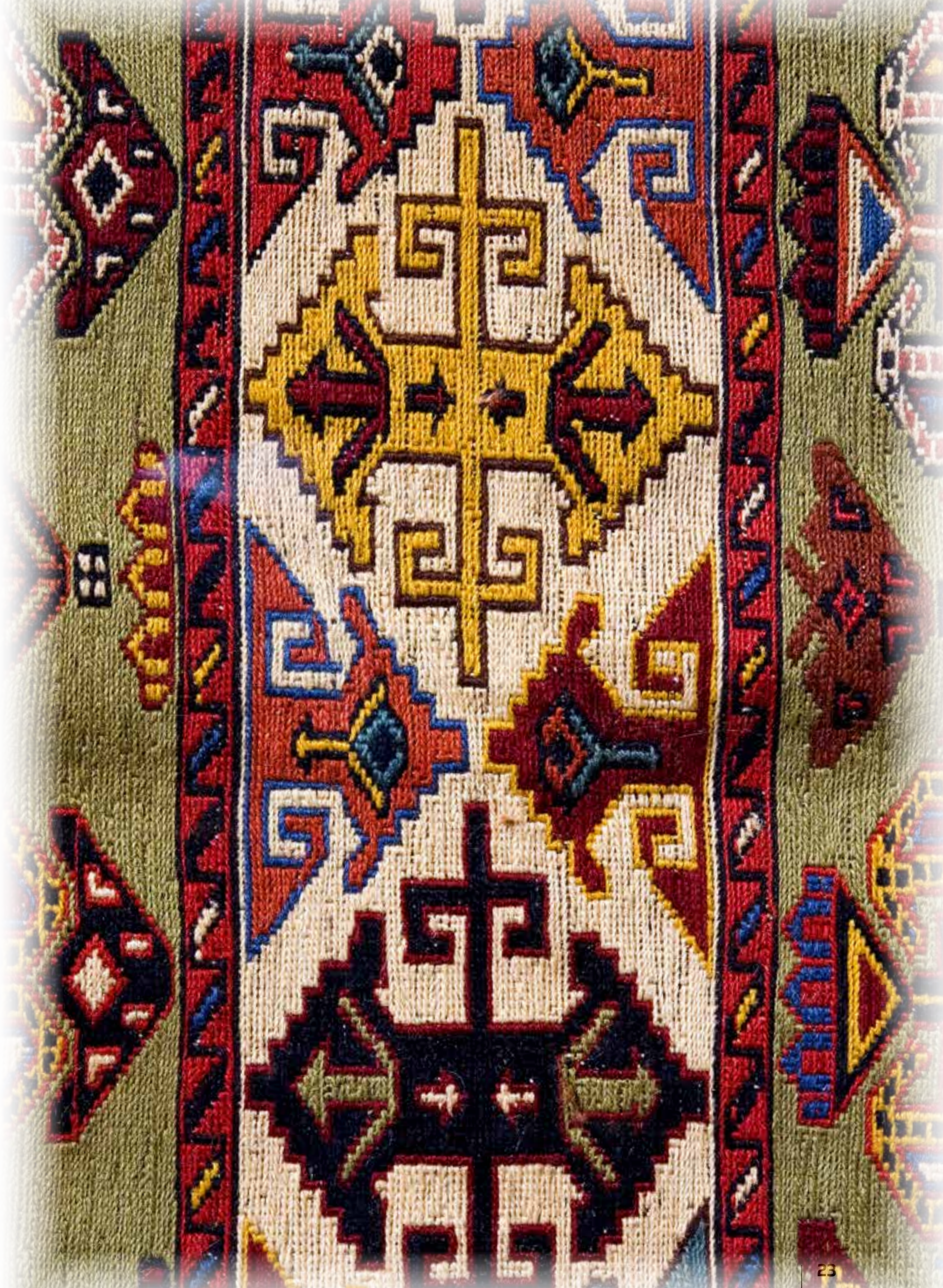


ağaçlarının yaprakları kullanılmıştır. Mordanl1 ve mordansiz olarak yapilan 84 boyamanın sonucunda sübjektif değerlendirme ile başta sarı rengin çeşitli tonları olmak üzere bej, kemik rengi, bal rengi, toprak rengi, hardal, kahverengi, gül kurusu, tarçın sarı-yeşil, yeşil kahve renkleri ile bu renklerin açı ve koyu tonları elde edilmiştir. Bu renk ve tonlar el dokuması halı ve kilimler için istenen renk ve tonlardir.

Genel olarak elde edilen bu renklerin 1şı ve sürtünme haslık değerleri orta, su damlası haslık değerleri ise iyi düzeydedir. El dokuması halı ve düz dokumalar için önemli olan bu haslık değerleri yapılan çalışmanın sonucunda orta ve iyi düzeyde değerler verdiği için, bu mordan, mordan oranı ve yöntemle boyanan ipliklerin halı ve düz dokumalarda kullanılması uygun olacaktır.

Sonuç olarak, el dokuması halı ve düz dokumacılığın yaygın olarak sürdürüldüğü Muğla ve çevresinde, yoğun olarak yetiştiriciliği yap1lan turunçgillerin yapraklarından elde edilen renklerin, gerek renk yönünden gerekse haslik değerleri yönünden el dokuması halı ve düz dokumalarda kullanılması önerilmektedir. Böylelikle yörede başka bir amaçla kullanılmayan, atıl durumdaki yaprakların da değerlendirilmesi sağlanacak ve başta Muğla ve çevresi olmak üzere dokumacılıkla uğraşılan yörelerde dokuma ipliklerinin renklendirilmesinde yeni bir renk kaynağı daha kazanılmış olacaktır.

\section{KAYNAKLAR}

Akgün, C. (2006). Turunçgiller Sektör Profili, Dıڤ̧ Ticaret Şubesi Uygulama Servisi.

Anonim (1970). DIN 5033 Farbmesung Begriffe der Farbmetrik Deutschland.

Anonim (1996a). Tekstil Renk Haslı̆̆ Tayin Metotları Bölüm A03 Renk Akmasının Değerlendirilmesinde Gri Skalalarn Kullanılması, TSE Yayınları, TS 423-3 EN 20105- A03. Ankara.
Anonim (1996b). Tekstil Renk Hasliğı Tayin Metotları Bölüm A02 Solmanın Değerlendirilmesinde Gri Skalanın Kullanılması, TSE Yayınları, TS 423-2 EN 20105-A02, Ankara.

Anonim (2005). "Turunçgil Yetiştiriciliği”, Batı Akdeniz Tarrmsal Araștırma Enstitüsü, Seminer Notlarl, Antalya.

Anonim (2006a). Tekstil-Renk Haslığ DeneyleriBölüm B02: Yapay Işı̆̆a Karşı Renk Hasliğının Tayini- Ksenon Ark Soldurma Lambası Deneyi, TSE Yayınları, TS EN ISO 105- B02/A1, Ankara.

Anonim (2006b). Tekstil-Renk Hasliğı Deneyleri-Bölüm X12: Sürtmeye Karşı Renk Hasliğı Tayini, TSE Yayınları, TS EN ISO 105-X12. Ankara

Anonim (2011a). Batı Akdeniz Tarımsal Araștırma Enstitüsü Raporları, Antalya.

Anonim (2011b). Ege Yaş Meyve Sebze İbracatçıları Birliği Raporları.

Anonim (2012). Tekstil Renk Hasliğı DeneyleriBölüm E07: Lekelenmeye Karşı Renk Hasliğı: Su, TSE Yayınları, TS EN ISO 105-E07, Ankara.

Baysal, K. (1973). “Türkiye'de Narenciye Üretimi ve İşlenmesi”, Türkiye'de Narenciye Üretimi, İslenmesi ve İhracatı Semineri, İktisadi Araştırmalar Vakfi. İstanbul.

Erdoğan, C. (2010). Mersin İlinde Narenciye Üretimi Katma Değer Tahmini, T.C. Başbakanlık Türkiye İstatistik Kurumu. Adana. (Basılmamış TÜİK Uzmanlık Tezi) .

Klein, M., P. Moore, C. Sweet, (1985). New and Familier, All About Citrus \& Subtropical Fruits. Editor: Lance Walheim, Monsanto Company. Canada.

Ladaniya, M.S (2008). Citrus Fruit, Academic Press-Elsevier. USA.

Nicolosi, E. (2007). Origin and Taxonomy, Citrus. Editor: Igrar Ahmad Khan. CABI. UK.

Timmer, L.W., S.M. Garnsey, J.H. Graham. (2000). Compendium of Citrus Diseases, The American Phytopathological Society, USA.

Yokaş, İ., (2004). Muğla İlinde Virüs ve Virüs Benzeri Hastalıklardan Arındırılmış Turunç Fidanı Üretim Projesi, Muğla Üniversitesi Yayınları: 51, Rektörlük Yayınları: 31. Muğla. 
